\title{
ASSESSMENT OF NATURAL AND CULTURAL LANDSCAPE CAPACITY TO PROPOSALS THE ECOLOGICAL MODEL OF TOURISM DEVELOPMENT (CASE STUDY FOR THE AREA OF THE ZAMAGURIE REGION)
}

\author{
MONIKA DRÁBOVÁ-DEGRO, ZDENA KRNÁČOVÁ*
}

Jurská 23, 83102 Bratislava, Slovak Republic; e-mail: drabova.monika@gmail.com

Institute of Landscape Ecology of SAS, Štefánikova 3, P.O.Box 254, 81499 Bratislava, Slovak Republic; e-mail: zdena. krnacova@savba.sk

${ }^{*}$ Author for correspondence

\begin{abstract}
Drábová-Degro M., Krnáčová Z.: Assessment of natural and cultural landscape capacity to proposals the ecological model of tourism development (case study for the area of the Zamagurie region). Ekológia (Bratislava), Vol. 36, No. 1, p. 69-87, 2017.

Agricultural and industrial conditions are not favourable in the uphill and mountain areas of the Zamagurie region, and tourism is often the only opportunity to create new jobs, develop the habitation areas and avoid the emigration of local inhabitants. The Walachian and Sholtys colonization has transformed the landscape and created unique significant spatial landscape elements that are traditionally utilized for agricultural purposes, and create a unique esthetical landscape preserved till the present times. This case study has been aimed at developing and applying the new quantification methods using GIS tools for evaluation of localizing, selective realization and environmental preconditions of the landscape, representing recreational (cultural) services of the landscape ecological systems, based on selected indicators. To evaluate the localizing preconditions of the landscape, we referred to the landscape-ecological complex geo-databases (LEC) (Thematic maps - internal ground document of ZB GIS , 2013), completed with the field survey during the period 2013-2014 and identification of secondary landscape structure elements (SLS) and selected morphometric indicators. While evaluating the selected town-planning, demographical and social-economic indicators, we quantified the selective landscape preconditions of tourism development. The realization preconditions were reviewed according to communication accessibility and material-technical equipment. As for environmental preconditions, we reviewed the presence of protected territory and landscape environmental load.
\end{abstract}

Key words: landscape, localization assumptions, selective assumptions, realization conditions, environmental assumptions, nature potential.

\section{Introduction}

Tourism is legitimately considered to be the main world economy area. UNWTO (United Nations World Tourism Organization) deals with the global issues of tourism and support 
of its development. It helps solve unemployment problems through creation of new job opportunities, contributing to GDP increase, creation of the state foreign exchange reserves. It contributes towards the preservation of historical archaeological monuments, protection of cultural values created by human generations, and preservation of natural beauties. These positive aspects could be reached if implemented on high professional levels (World Tourism Organization (WTO), 2004).

The landscape tourism potential represents an objective landscape capability to provide for the tourism development conditions (Mariot, 1983). Tourism development in a particular territory depends first of all on the preconditions of the territory. These preconditions are expressed either through local country and nature attractiveness, or cultural-historical attractions and communication accessibility. Natural preconditions are of relatively time-stable nature, representing the major factors of a certain territory. Natural attractiveness of the territory is given by its geo-morphological, climatic, hydrological and biological conditions.

According to Kopšo et al. (1992), the landscape potential comprises potential created by the activity of the society and the natural potential to utilize opportunities in the area of tourism due to its variety of species, level of attractiveness and quality of natural attractions.

There are various approaches to research of tourism. Some of the authors, for example McIntosh, Goeldner (1990) classified the tourism research approaches as institutional, historical, organizational, economic, sociological, geographical interdisciplinary ones and those entering through tourism products. Interdisciplinary approach is necessary for cross-sectional research type. Williams (2004) stated that tourism is neither an independent scientific theory nor a scientific specialization. Tourism represents the centre of attention of other scientific specializations such as geography, sociology, anthropology, economy and psychology.

Tourism as a scientific specialization had missed sufficient academic support for a long time before it intersected with planning, recreation, geography, economy, transportation and other sectors. Many recognized authors recommend using a more balanced approach through the development of more methodically elaborated articles about research, using suitable statistical techniques based on strong theoretical principles. The aim of such a trend is to gradually create conditions for tourism development as a recognized scientific specialization. This is feasible through application of scientific methods and interdisciplinary approaches based on mathematical-statistical methods and GIS tools.

As mentioned earlier, Mariot (1983), Warszynska, Jackowski (1978), Kopšo et al. (1992), Krogmann (2005a,b; 2006), Kaspar (1995), Horner, Swarbrooke (2003), Otrubová (1996), Nováková, Frantál (2007), Krnáčová et al. (2005) dealt with the evaluation of landscape recreational potential mainly from a geographical point of view.

The presented case study is dedicated to rural tourism in the area of the Zamagurie region. It includes travelling to and staying in rural environment (Vanslenbrouck, Huylenbroe$\mathrm{ck}, 2005)$. Rural tourism is characterized as a vacation, motivated mainly by the desire for experiences in rural area, becoming familiar with rural inhabitants, heritage and traditional lifestyle (Hall et al., 2005). Rural tourism represents the system of recreational activities related to rural environment, and it differs from traditional mass-tourism activities (even if a few of them include swimming, skiing, etc.). It represents return to the nature and traditions. These activities are usually associated with the stay in the nature, where people stay with 
village families in rural houses and accommodation facilities (Gondová et al., 2000). It is a special form of recreation in the rural environment, using various features offered by this environment (meadows, forests, fishponds, rivers, local handicrafts, folklore, etc.). People interested in rural recreation are offered with services using free capacities of rural houses, shopping, accommodation, boarding and sport facilities.

\section{Methodical processes}

Determination of the country's potential in relation to the development of tourism in the selected region of Zamagurie requires integration of GIS tools and methods of complex evaluation of the monitored territory. To interpret the landscape recreational offer, we chose suitable indicators of natural and socio-economic character, to which we assigned quantified values and degrees of probable active participation from the social-economic sector for the purpose of development of selected recreational activities, based on the selected methodical processes.

Localizing (natural) preconditions of tourism development (NTP), first of all, creates the natural conditions for tourism. It comprises of landscape components that represent the basis for landscape potential evaluation. In the localizing preconditions of tourism development, we evaluate:

- the natural conditions (geo-morphological, climate and biotope conditions),

- the secondary landscape structure (the group of tree and bush vegetation, grass - herb vegetation, the group of subsoil and raw soil baring, surface water and wetlands, and the group of residential and built-up areas).

To evaluate the landscape nature potential, we referred to the landscape ecological complex geo-databases (LEC) (Thematic maps - internal ground document of ZB GIS2013) with identification of the secondary landscape structure elements (SLS) and the selected morphometric indicators. Quasi-homogenous units - morphotopes - represented the basis for LEC selection. These were created according to the relief digital models (DMR) and deduced morphometric parameters with the screen resolution 10x10 m. Preliminary map of the so called major factor was created through subsequent superposition with the landscape coverage layer (SLS). Such created major factor areas were filled with the landscape characteristics, taking into account the data contextual non-controversy. Relief characteristics were deduced through spatial statistics from DMR, calculated as average values for particular LEC polygons. We conducted field surveys during period of years 2013-2014, aimed at specifying the map units in details and verifying them. We arranged the map key words according to the work of the authors Petrovič et al. (2009); putting aside 28 independent landscape elements in the monitored territory of six landscape element groups.

To calculate the landscape nature potential, we set forth selected mapping elements of the secondary landscape structure, which we considered adequate for the development of tourism (tree and bush vegetation, grass - herb vegetation, extensively utilized meadows and pasture land, as well as extensive small-area orchards for agricultural cultures, and rock peaks, rock walls and surface waters).

To ensure quantified estimation of the landscape natural tourism potential (NTP), we applied the mathematical relation of Nováková, Frantál (2007), modified by Krnáčová (2014), Drábová (2015):

$$
P P C R=\sum_{i=1}^{n}\left[C_{1-5} * \sum(L * I)_{1-5}\right] \text {, }
$$

where:

$\mathrm{C}_{1-5}$ - average LEC polygon sloppiness in the territory of cadastre $\mathrm{C}\left(\mathrm{C}_{1}-\right.$ very low $0^{\circ}-3^{\circ}, \mathrm{C}_{2}-$ low $3^{\circ}-7^{\circ}, \mathrm{C}_{3}-$ medium $-7^{\circ}-12^{\circ}, \mathrm{C}_{4}-$ high $12^{\circ}-25^{\circ}, \mathrm{C}_{5}$ - very high, above $\left.25^{\circ}\right)$,

$L$ - percentage share of LEC areas, in particular sloppiness on the cadastre area, suitable for tourism,

$I$ - polygon shape index,

$$
I=\frac{P}{(2 \sqrt{A \cdot n})},
$$

where:

$P$ - sum of perimeters of selected LEC elements, in particular sloppiness on the cadastre area, suitable for tourism, $A$ - sum of LEC elements areas, in particular sloppiness on the cadastre area,

$n$ - number of LEC elements, in particular sloppiness on the cadastre area, 
$I$ - constant that express the extent of the round shape of LEC polygon.

Constant $=1$ in case of round LEC area.

\section{Localizing semi-natural and cultural-historical preconditions}

In order to determine the cultural - historical, half-natural country preconditions, we mapped the presence of preserved traditional agricultural cultures (HSAL) in the landscape and their area extent within the territory. Based on the area, particular indicators were assigned with the significance class and the share of the precondition on tourism development: 1 - expected smaller tourism development based on HSAL area, 2 - expected medium tourism development based on HŠPK area, 3 - expected high tourism development based on HŠPK area.

Military terrain maps of the former Czechoslovakia from ILE SAS archive with the scale 1: 25 000, (dated in 1957) with the coordinate system S42 were used as the grounds for mapping the selected historical nature structure elements.

Selective preconditions indicate capability of the inhabitants to participate in tourism, determining the nature and size of demand from an economic point of view (Mariot, 1983). In the selective tourism preconditions, we evaluated:

- Urban planning preconditions - Identifying them on the basis of residence size analysis and habitation fund.

- Demographical preconditions - Indicators: population development, population age structure, gender structure, nationality structure and religion structure.

- Social-economic preconditions - Indicators: education structure of population, economic activities, social affiliation of population and living standard indicators.

Realization preconditions - They allowed for the implementation of tourism participants' demands in the area of most favourable preconditions for the development of tourism (Ferner, 1993). Mariot (1983) classifies realization preconditions as follows:

- Communication preconditions - In this section, we dealt with the structure of communication network, time accessibility of the locations, and tourist pathways. Time accessibility of locations was determined according to the methodology described in the work of Mariot (1983), stating $15 \mathrm{~min}$ for short-term recreation. We classified communication accessibility and quantification of communication preconditions of particular settlements into 3 categories (Krnáčová et al., 2005): 1 - less accessible - more than 30 min, 2 - accessible - 15 through 30 min, 3 - well accessible - less $15 \mathrm{~min}$.

- $\quad$ Material -technical preconditions - We evaluated accommodation facilities, boarding facilities, the transport equipment, other preconditions. Service category was determined in the case of accommodation and boarding facilities: 1 - low level of service, 2 - medium level of service, and 3 - higher level of service.

Environmental preconditions - They point out to the positive and adverse events and elements in the country, existing in the form of regulations, standards and laws, of tangible and intangible nature:

- Landscape protection - Analyzed: protected territories, natural sources, cultural - historical monuments, historical development of the territory, tangible cultural - historical monuments and intangible cultural - historical monuments.

- $\quad$ Stress factors - We analyzed tangible and intangible stress factors.

Methodology is presented in scheme 1 .

\section{Model territory}

We chose the following areas of the Stará L'ubovňa district as the monitored territory: Haligovce, Velký Lipník, Lesnica and Stráňany, and Červený Kláštor and Lechnica in the district Kežmarok. From administration posit of view, the northern boundary of the territory of interest passes through the state border between Slovakia and Poland. In the West, its neighbouring villages are Majere and Spišská Stará Ves, and in the South, villages Hava, Velká Lesná, Toporec, Podolínec, Vyšné Ružbachy, Lackova and Hniezdne. In the East, its neighbours are the villages Kamienka, Jarabina and Litmanová. All the named villages are included in the district Stará Lubovňa. Total area of the monitored territory refers to 8,055.6 ha, representing also a part of the smallest Slovak national park Pieniny (PIENAP). Total area of the Pieniny National Park refers to 3,725.4 ha and protected zone covers 22,508.6 ha.

\section{Characteristics of the territory}

The territory in question has specific location in the intersection of the Pieniny and the Spišská Magura mountains in Slovakia, and the Polish part of the Beskydy mountains in Poland. Therefore, the orographic conditions play 


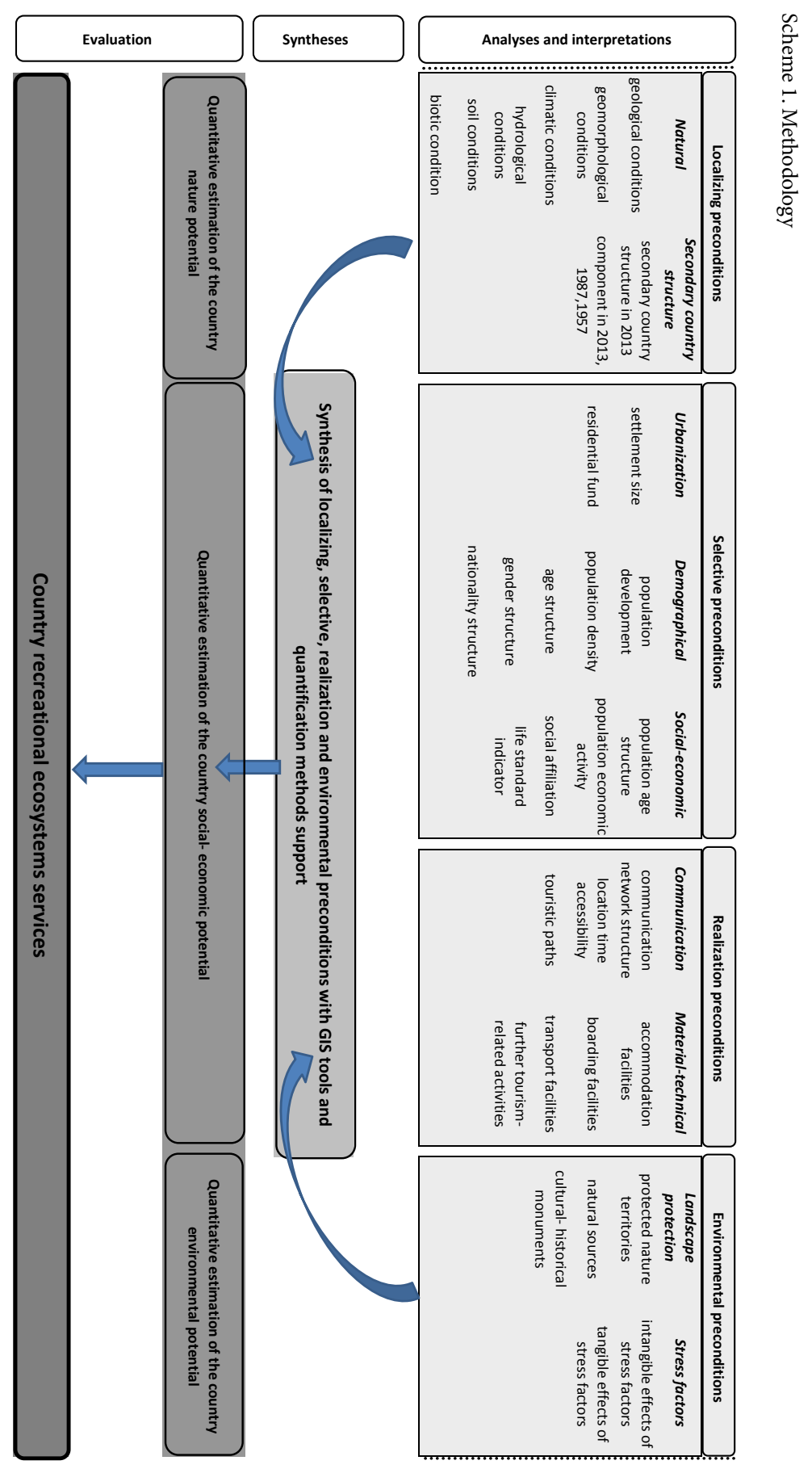


a significant role in the local climate forming. It results from the general climate characteristics that the Pieniny Mountains belong to the coolest areas of the Slovak Republic (Fig. 1).

Relief properties play an important role when evaluating tourism potential of the landscape. The evaluation of the relief dissection, and in particular, the relief forms is important mainly in the terms of attractiveness to the tourists. The whole monitored territory is situated in the Pieniny mountains geo-morphological unit, integrated in the Eastern Beskydy area belonging to the Outer Western Carpathian sub-province and Western Carpathian province (Mazúr, Lukniš, 1986). The climate impact on the selected activities localizing is significant in the monitored territory. The differentiation factor results from the relief configuration (valleys, basins); with extremely strong effect when considering certain activities and territory utilization.

Natural conditions of the territory - geological structure, relief, climate, waters and soils represent the basis for various forest vegetation associations. In terms of phyto-geographical structure, according to Futák (1972), the territory belongs to the Western-Carpathian flora (Carpaticum occidentale), the Central-Carpathian zone flora (Eucarpaticum), and the district of Pieniny.

As stated in the Pieniny National Park Report (www.pienap.sk), despite of anthropological interventions, the forest associations present in the monitored territory are well preserved. The most preserved associations - natural biocenose types are located in the National Park zone A at the former natural reservations. Three forest vegetation classes contribute to the forest associations' variety: oak-beech, beech and fir-vegetation class. Zoological extraordinariness has been conditioned by various factors in the Pieniny territory: the area that was not covered by continuous glacier in the past, significant geo-morphological topography and the rich geological bedding. Despite being a small territory, these factors provide optimum life conditions to particular Pieniny fauna species' populations. Pursuant to the adopted zoological- geographical regionalization of Slovakia, the Pieniny has been included in the Western-Carpathian zone of the Carpathian Mountains sub-province and the province of hardwood forests (Jedlička, Kalivodová, 2002).

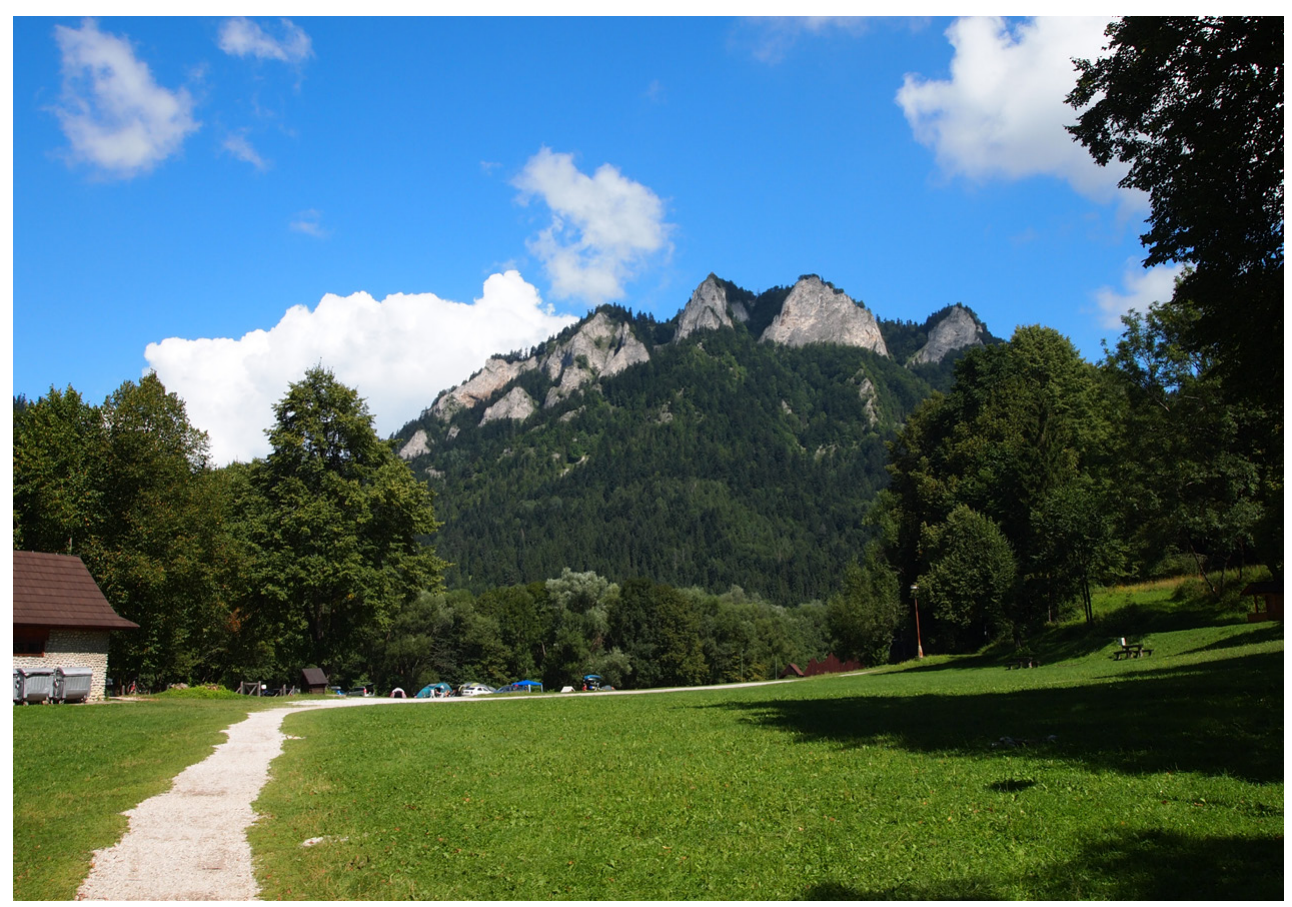

Fig. 1. The Pieniny National Park (PIENAP) represents huge natural potential for the tourism development in the Zamagurie region. (Photo: PIENAP archive, 2014). 


\section{Secondary landscape structure (SLS)}

Secondary landscape structure has high narrative value in terms of current status of biotic component and economic utilization of the territory, and spatial layout of landscape components. Specification of landscape components belongs to the fundamental knowledge on ecological properties and values of the landscape (Fig. 2). To classify the components that create physiognomic-economic units of the landscape, we applied the landscape component mapping legend to the monitored territory, according to the work of Petrovič et al. (2009). During mapping and analysis, we methodically referred to six groups of landscape components: 1. the group of tree and bush vegetation, 2 . the group of grass - herb vegetation, 3. the group of agricultural cultures, 4 . the group of subsoil and baring raw soil, 5 . the group of surface water and wetlands, and 6. the group of residential and built-up areas. Within the six natural component groups, we put aside 28 independent landscape elements. The complete list of natural component groups and natural components, including the area covered in the monitored territory, is contained in Table 1.

T a b l e 1. Area of SLS components in the monitored territory (period of years 2013-2014).

\begin{tabular}{|c|c|c|c|c|}
\hline \multirow[t]{2}{*}{ SLS group } & \multicolumn{2}{|c|}{ SLS group area } & \multirow[t]{2}{*}{ SLS component } & \multirow{2}{*}{$\frac{\text { SLS component area }}{(\mathrm{ha})}$} \\
\hline & (ha) & $\%$ & & \\
\hline \multirow{5}{*}{$\begin{array}{l}\text { 1. tree and bush } \\
\text { vegetation }\end{array}$} & \multirow[t]{5}{*}{$4,937.9$} & \multirow[t]{5}{*}{61.30} & 1.1 Continuous hardwood forests & 335.95 \\
\hline & & & 1.2 Continuous softwood forests & $3,889.08$ \\
\hline & & & 1.3 Continuous mixed forests & 336.5 \\
\hline & & & 1.4 River bank woods & 359.2 \\
\hline & & & 1.5 Leafy bush vegetation & 17.14 \\
\hline $\begin{array}{l}\text { 2. grass - herb } \\
\text { vegetation }\end{array}$ & $2,262.3$ & 28.03 & 2.2 Extensive pastures & $1,190.67$ \\
\hline \multirow{4}{*}{$\begin{array}{l}\text { 3. agricultural } \\
\text { cultures }\end{array}$} & \multirow[t]{4}{*}{679.4} & \multirow[t]{4}{*}{8.43} & 3.1 Large size fields & 8.19 \\
\hline & & & 3.2 Small size fields & 574.77 \\
\hline & & & 3.3 Residential gardens & 87.87 \\
\hline & & & 3.4 Extensive small size orchards & 8.54 \\
\hline $\begin{array}{l}\text { 4. subsoil and } \\
\text { baring raw soil }\end{array}$ & 11.3 & 0.14 & 4.1 Rock peaks, ridges, faces & 11.25 \\
\hline \multirow{2}{*}{$\begin{array}{l}\text { 5. surface water } \\
\text { and wetlands }\end{array}$} & \multirow[t]{2}{*}{34.2} & \multirow[t]{2}{*}{0.43} & 5.1 Unregulated rivers & 30.27 \\
\hline & & & 5.2 Fishponds, fish water tanks & 3.97 \\
\hline \multirow{14}{*}{$\begin{array}{l}\text { 6. residential } \\
\text { and built-up } \\
\text { areas }\end{array}$} & \multirow[t]{14}{*}{130.5} & \multirow[t]{14}{*}{1.62} & 6.1 Continuous individual residential buildings & 85.92 \\
\hline & & & 6.2 Churches and chapels & 0.87 \\
\hline & & & 6.3 Monasteries & 1.52 \\
\hline & & & 6.4 Cemeteries & 5.13 \\
\hline & & & 6.5 Lawns & 5.02 \\
\hline & & & 6.6 Grass sport areas & 3.44 \\
\hline & & & 6.7 Unstructured recreational objects & 0.3 \\
\hline & & & 6.8 Hotels and spa resorts & 7.68 \\
\hline & & & 6.9 Summer house settlements & 0.41 \\
\hline & & & 6.10 Beaches & 2.36 \\
\hline & & & $\begin{array}{l}\text { 6.11 Industrial and technical areas - unstruc- } \\
\text { tured }\end{array}$ & 2.98 \\
\hline & & & 6.12 Unstructured agricultural areas & 12.73 \\
\hline & & & 6.13 Re-cultivated areas of landfill and storage & 0.45 \\
\hline & & & 6.14 Parking lots and docks & 1.79 \\
\hline Total: & $8,055.6$ & 100.0 & & $8,055.6$ \\
\hline
\end{tabular}


The area coverage by the component groups in the monitored territory is as follows: Ranked 1 is the group of tree and bush vegetation that covers the largest area - more than $50 \%$ of the territory $(61.30 \%)$. In the terms of the area, the group of grass - herb vegetation is ranked as 2 nd with $28.03 \%$ of coverage, followed by the group of agricultural cultures $(8.43 \%)$. The 6th group of residential and built-up area covers $1.62 \%$ of the monitored territory, followed by the group of surface water and wetlands $(0.43 \%)$. The smallest group in the terms of covered area refers to the group of subsoil and the baring raw soil $(0.14 \%)$.

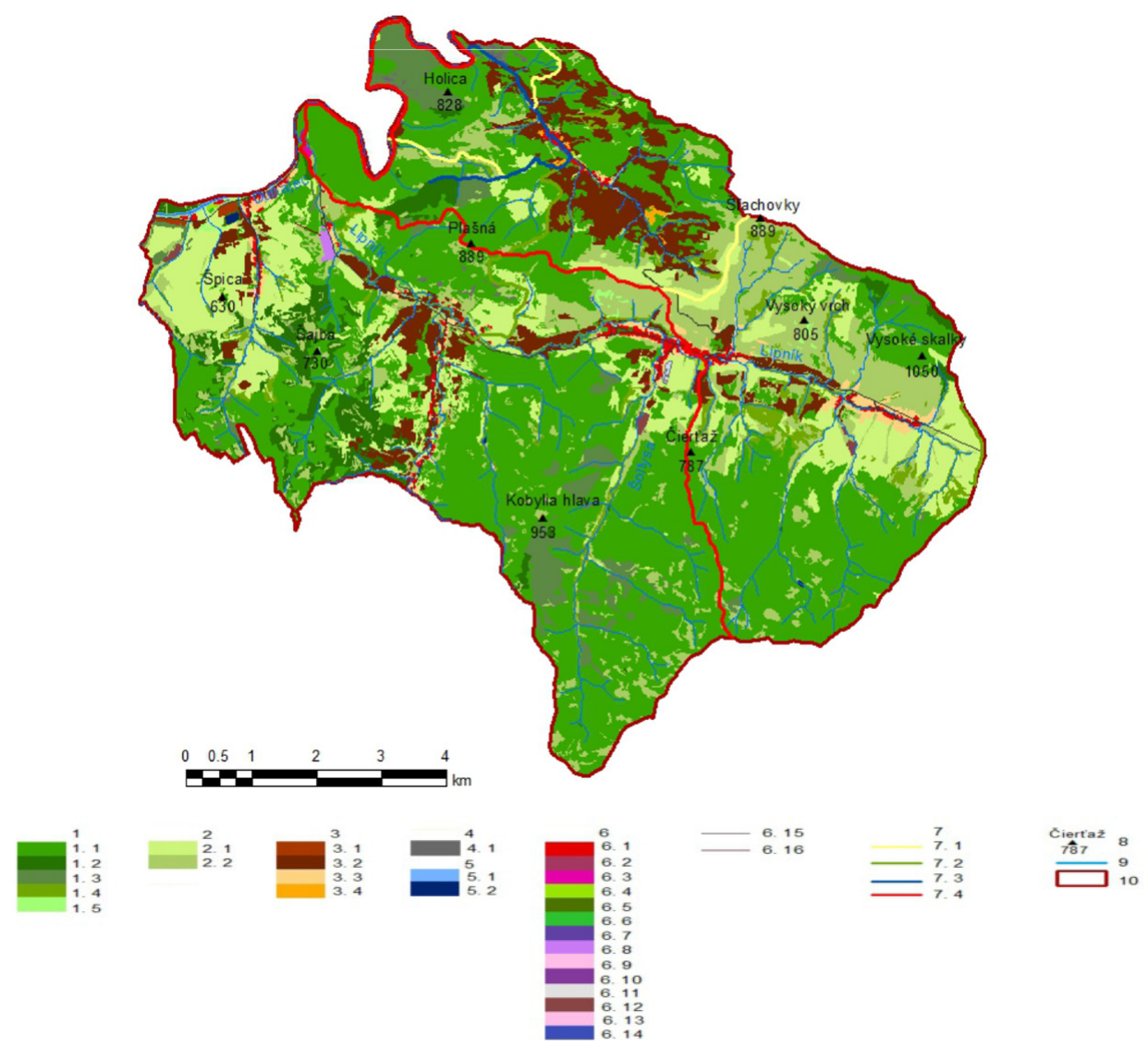

Fig. 2. Secondary landscape structure (SLS) of the Zamagurie region.

Notes: 1 - group of tree and bush vegetation: 1.1 - continuous hardwood forests, 1.2 - continuous softwood forests, 1.3 - continuous mixed forests, 1.4 - river bank woods, 1.5 - leafy bush vegetation, 2 - group of grass - herb vegetation 2.1 -extensive meadows, 2.2 - extensive pasture land without woods, 3 - group of agricultural cultures: 3.1 - large size fields, 3.2 - small size fields, 3.3 - residential production gardens, 3.4 - extensive small size orchards, 4 - group of subsoil and raw soil baring: 4.1 - rock peaks, ridges, faces, 5 - group of surface water and wetlands: 5.1 - not regulated rivers, 5.2 - fishponds, fish water tanks, 6 - group of residential and built-up areas: 6.1 - continuous individual residential buildings, 6.2 - churches and chapels, 6.3 - monasteries, 6.4 - cemeteries, 6.5 - lawns, 6.6 - grass sport areas, 6.7 - not structured recreational objects, 6.8 - hotel and spa resorts, 6.9 - summer house settlements, 6.10 - beaches, 6.11 - industrial and technical areas - unstructured, 6.12 - unstructured agricultural areas, 6.13 - re-cultivated areas of landfill and storage, 6.14 - parking lots and docks, 6.15 - main roads, 6.16 - cable car routes; 7 - tourist paths: 7.1 - yellow signed, 7.2 - green signed, 7.3 - blue signed, 7.4 - red signed; Other signs: 8 - elevation mark, 9 - flow, 10 - boundary of monitored territory. 


\section{Results and discussion}

\section{Localizing (natural) preconditions of tourism development (NTP)}

We prepared quantified estimation of the natural tourism potential (NTP) for the cadastre territory of the Zamagurie region pursuant to the methodology of authors Nováková, Frantál (2007), modified by authors Drábová (2015), and Krnáčová (2014). Despite the importance of natural potential calculation, it represents only a partial result and shouldn't be identified as a total potential of tourism, since the cultural sub-system components could hugely contribute to the whole territory potential. We obtained the following values from the application and mathematical calculation: Červený Kláštor (NTP-666), Lesnica (NTP-722), Lechnica (NTP-865), Stráňany (NTP-874), Haligovce (NTP-878) and Velký Lipník (NTP-883). Furthermore, we assigned PPCR mark to particular locations, referring to the data: Červený Kláštor - 1 (the lowest value); as a result of low assessment of components suitable for tourism. Location Lesnica - 2 (very low value) - prevailing small-area agricultural zones that don't belong to PPCR components. Tables 2 and 3 show the examples of natural potential quantification - cadastre of Lechnica and Stráňany.

T a b l e 2. Example of the landscape nature potential quantification (NTP) - cadastre Lechnica.

\begin{tabular}{|l|c|c|c|c|c|c|c|c|}
\hline & $\begin{array}{c}\text { Area of SLS } \\
\text { components suitable } \\
\text { for tourism } \mathbf{( m}^{\mathbf{2}}\end{array}$ & Sloppiness & $\left.\mathbf{P} \mathbf{( m}^{2}\right)$ & $\mathbf{n}$ & $\mathbf{I}$ & $\mathbf{L}$ & $\mathbf{C x}$ & $\mathbf{C}$ \\
\cline { 2 - 9 } & $818,437.3$ & $0^{\circ}-3^{\circ}$ & $69,990.2$ & 117 & 3.6 & 6.6 & 1 & 23.6 \\
\cline { 2 - 9 } & $191,809.0$ & $3-7^{\circ}$ & $18,356.2$ & 48 & 3.0 & 1.5 & 2 & 9.3 \\
\cline { 2 - 9 } & $2,053,612.1$ & $7^{\circ}-12^{\circ}$ & $125,439.7$ & 286 & 2.6 & 16.5 & 3 & 128.3 \\
\cline { 2 - 9 } & $7,844,109.7$ & $12^{\circ}-25^{\circ}$ & $325,852.1$ & 1,290 & 2.6 & 63.1 & 4 & 660.1 \\
\cline { 2 - 9 } NTP Lechnica & $426,711.2$ & above $25^{\circ}$ & $22,384.9$ & 46 & 2.5 & 3.4 & 5 & 43,4 \\
\hline Total: & $\mathbf{1 1 , 3 3 4 , 6 7 9 . 3}$ & & $762,023.2$ & 1,787 & & & & NTP-864.7 \\
\hline Total per cadastre: & $\mathbf{1 2 , 4 2 4 , 2 5 6 . 5}$ & & & & & & & \\
\hline
\end{tabular}

T a b l e 3. Example of the landscape nature potential quantification (NTP) - cadastre Stráňany.

\begin{tabular}{|l|c|c|c|c|c|c|c|c|}
\hline & $\begin{array}{c}\text { Area of SLS } \\
\text { components suitable } \\
\text { for tourism } \mathbf{( m}^{\mathbf{2}}\end{array}$ & Sloppiness & $\mathbf{P}\left(\mathbf{m}^{2}\right)$ & $\mathbf{n}$ & $\mathbf{I}$ & $\mathbf{L}$ & $\mathbf{C x}$ & $\mathbf{C}$ \\
\cline { 2 - 9 } & $99,126.4$ & $0^{\circ}-3^{\circ}$ & $19,464.0$ & 11 & 9.3 & 0.9 & 1 & 8.0 \\
\cline { 2 - 9 } & $140,348.7$ & $3-7^{\circ}$ & $6,923.7$ & 15 & 2.4 & 1.2 & 2 & 5.8 \\
\cline { 2 - 9 } & $1,184,245.8$ & $7^{\circ}-12^{\circ}$ & $76,993.6$ & 179 & 2.3 & 10.2 & 3 & 80.9 \\
\cline { 2 - 10 } & $8,206,427.7$ & $12^{\circ}-25^{\circ}$ & $428,574.4$ & 891 & 2.5 & 70.7 & 4 & 708.7 \\
\cline { 2 - 10 } NTP Stránany & $762,556.2$ & above $25^{\circ}$ & $34,578.4$ & 84 & 2.1 & 6.6 & 5 & 71.0 \\
\hline Total: & $\mathbf{1 0 , 3 9 2 , 7 0 4 . 9}$ & & $566,534.1$ & 1,180 & & 89.5 & & NTP-874.4 \\
\hline Total per cadastre: & $\mathbf{1 1 , 6 0 6 , 5 7 4 . 4}$ & & & & & & & \\
\hline
\end{tabular}




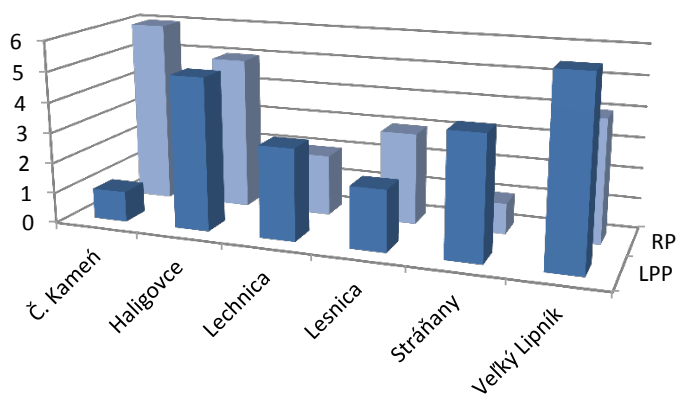

Fig. 3. Comparison of total recreational potential (RP) to localizing natural potential (LPP).

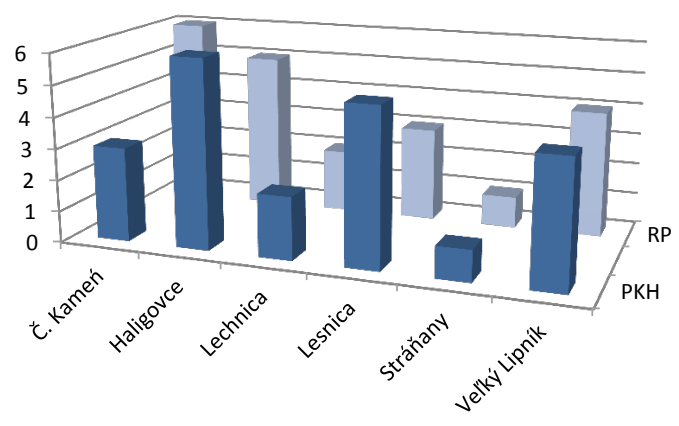

Fig. 4. Comparison of total recreational potential (RP) to culturalhistorical potential $(\mathrm{PKH})$.

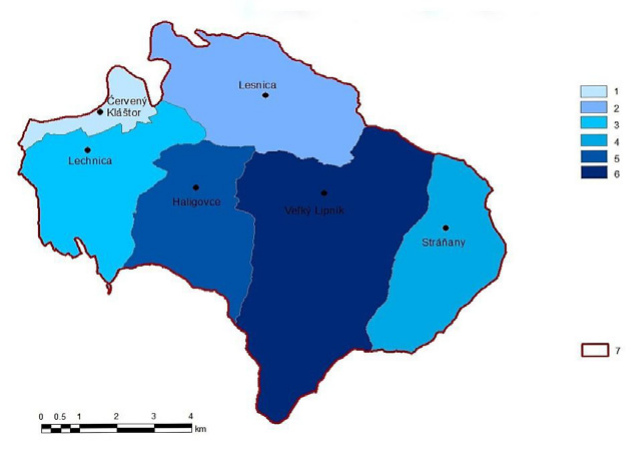

Fig. 5. Spatial image of natural potential (NTP).

Notes: 1- lowest, 2 - very low, 3- low, 4-moderate, 5-high, 6-very high.

Dominant grass vegetation and valley location is present on the Lesnica creek bottom land. Small-size field zones (HSAL) of the area 5.97 ha are located in the village Červený Kláštor,
Localizing semi-natural and cultural - historical preconditions for tourism (PKH)

The occurrence of historical landscape structures represented an indicator of the stated localizing preconditions. These represent a relict of cultural heritage and anthropological activities in the landscape, preserved till the present times. They often occur in isolated fragments, but the mentioned relict forms usually occur in each SLS.

The largest area of terrace fields is located at Velký Lipník village $104.01 \mathrm{ha}$. The shape of the historical agricultural landscape structures (HSAL) zones, concentrated in the northern part of the rural area, mainly comprises of permanent grass vegetation. A strip of small-size field (HSAL) zones is located at the village Haligovce in the South-North direction having an area of 116.52 ha. These small-size fields are usually located on the slopes covered by grass, bush-tree and dominant bush vegetation on the balks and terraces. Village Lesnica has the largest area of small-size fields (HSAL (306.56 ha), with two shapes of small-size fields (HSAL) present: a block-shape of small-size fields (HSAL), with the area 272.63 ha, is mostly concentrated in the South-Eastern rural zone. This area is mostly sloped with grass vegetation on the dominant balks. Small-size field zones (HSAL)of the area 33.93 ha are located in the northern rural area of village Lesnica. 
mostly on the bottom land without anthropogenic form. Regarding the village Stráňany, there are also smallsize field (HSAL) zones of the area 1.1 ha on the slopes along the village residential area, anthropogenic form.

Fig. 5 and Fig. 6 compare the total recreational potential (RP) to the landscape natural potential (LTP). Fig. 3 and Fig. 4 compare the total recreational potential (RP) to the landscape cultural -historical potential.

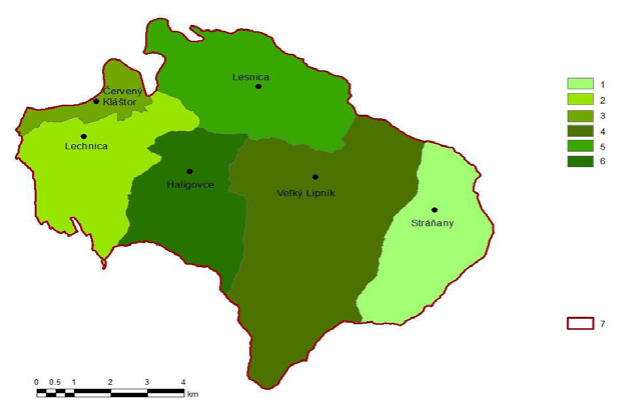

Fig. 6. Spatial image of cultural-historical potential (CHP).

Notes: 1- lowest, 2 - very low, 3- low, 4-moderate, 5-high, 6- very high.

\section{Selective preconditions of tourism development}

Selective preconditions indicate the capability of participating in tourism, determining the nature and extent of demand and taking into account the economic aspect. We divided the selective preconditions into:

- urban-planning,

- demographic,

- $\quad$ social - economic preconditions.

In these selective precondition groups, we dealt with selected indicators on the village level. Based on the percentage share of active participation of the population in tourism, we assigned likelihood rate of population participation in tourism to particular villages/ towns and applied it subsequently to the synthesis and evaluation (Krnáčová et al., 2005).

\section{Urban-planning preconditions}

We determined the likelihood rate of population participation in tourism according to the latest census (Statistical Annual Report of the Slovak Republic, 2002). Particular rates: 1 fewer than 250 inhabitants, 2 - within 251 - 600 inhabitants, 3 - 601 inhabitants and more. It resulted from the evaluation that villages Vel'ký Lipník and Haligovce show the highest likelihood rate of population participation in tourism. The likelihood rate of participation in tourism was calculated from the obtained data on residential area per capita, namely: 1 more than $26.6 \mathrm{~m}^{2}, 2-26.1-26.6 \mathrm{~m}^{2}, 3$ - less than $26.1 \mathrm{~m}^{2}$.

Based on the criterion - average residential area in $\mathrm{m}^{2}$ per capita, we calculated the highest likelihood of participation in tourism at the cadastre territory Červený Kláštor and Stráňany.

\section{Demographic preconditions}

According to Mariot (1983), the demographic parameters indicating different attitudes to participation in short-term and long-term tourism belong to selective preconditions of tour- 
ism, namely: population density, age structure, and gender structure. The monitored territory belongs to territories typical with religion and national variety, thus we added the information on the national and religious structure of the population.

Population headcount development was subject to the effects of various factors. The landscape nature of the territory in question is mountainous with not very fertile soil that has caused complicated conditions for the local farmers. At the end of the $19^{\text {th }}$ and at the beginning of the $20^{\text {th }}$ century, poor agricultural conditions, undeveloped agricultural system and lack of workforce have resulted in the emigration of local inhabitants in to the USA, Canada and Ukraine. Life cycle conditions of the local population were worsened also by historical events, along with poor natural conditions. Male population prevails almost in all rural settlements except Červený Kláštor (54.85\%) and Stráňany (51.24\%) with prevailing female population.

The most likely active participation of population in tourism, in the terms of population density, is in the villages Červený Kláštor and Haligovce. Less likely participation is in the villages Lesnica and Velký Lipník; and the lowest likelihood is in the villages Lechnica and Stráňany.

Taking in account the data availability from the Slovak Statistical Office, main concentration centres of potential interest in tourism are in the villages with population in active life (men within 15 - 59 years, and women within 15 - 54 year of age). We determined the likelihood rate of population participation in tourism according to the productive element share, with particular rates: 1 - less than $60.4 \%, 2$ - within $60.4-60.9 \%$, and 3 - more than $60.9 \%$. The villages Červený Kláštor and Haligovce showed the highest likelihood of active participation of population in tourism in the terms of age structure. The villages Lechnica and Velký Lipník showed lower likelihood, considering the state criterion, and villages Lesnica and Stráňany showed the lowest likelihood of active participation of population in tourism in terms of age structure. Villages Lechnica, Lesnica and Haligovce are significant in relation to the interest in development of tourism in the future (pre-productive age ratio). Table 4 shows an overview of the evaluated indicators.

\section{Social-economic preconditions}

Urban-planning and demographic preconditions of tourism development represent only a part of the selective preconditions. Adding socio-economic preconditions thereto, we are able to better define actual interest of the population in the participation in tourism. We included education structure, economic activity, social affiliation and life standard indicators in the socio-economic preconditions of tourism development in the monitored territory, which indirectly indicate the population income. Population's economic activity is considered to be the most significant indicator. Economic-active inhabitants are those showing the highest interest in participation in tourism, mainly in one-day, weekend and vacation tourism. Headcount of economic-active inhabitants of the monitored territory referred to 1,246 people in 2011 , corresponding to $43 \%$ of population in the monitored territory. Of all the economicactive people, there were $60.1 \%$ men and $39.9 \%$ women. We deduced the likelihood rates from the data on economic-active inhabitants of the monitored territory as follows: 1 - fewer than $42.1 \%, 2$ - within $42.1-43.5 \%$, and 3 - more than $43.5 \%$. Table 4 shows an overview 
of the evaluated indicators. Villages Velký Lipník and Haligovce show the highest likelihood of active participation of inhabitants in tourism. The villages Červený Kláštor and Lechnica show lower likelihood, and the villages Stráňany and Lesnica show the lowest likelihood.

\section{Realization preconditions of tourism development}

The evaluation of realization preconditions comprises of the evaluation of communication preconditions and material-technical preconditions. Communication preconditions were created from the inner time accessibility of the recreational destinations at the monitored villages, based on bus and car transportation possibilities. Favourable accessibility of the region contributes to total territorial attractiveness in terms of its potential visitors. On the contrary, poor accessibility of the region could result in not enough tourists or to their outflow to towns or regions that are better accessible. Accessibility also significantly affects the length and frequency of tourist travels and stays. The frequency of transport lines, their number, time of arrival/departure and the structure of particular lines according to the available public transport means, and transport time when using public transport mean is important when thinking about tourism (Michniak, 2014). Wieckowski et al. (2012) applied isochrones to the time accessibility analysis - they are lines connecting the points with the same distance from certain place, expressed in time units. Villages Velký Lipník and Červený Kláštor showed the best communication preconditions.

We applied the so called 'bal' value to quantitative evaluation of material-technical preconditions. The highest value was assigned to hoteltype recreational facilities offering a wide range of services from boarding, accommodation, relaxation, sports, organization of cultural - societal events and conferences. The villages Červený Kláštor and Lesnica showed the best material - technical preconditions when evaluating this criterion. Fig. 7 and Fig. 9 show the comparison of total recreational po-

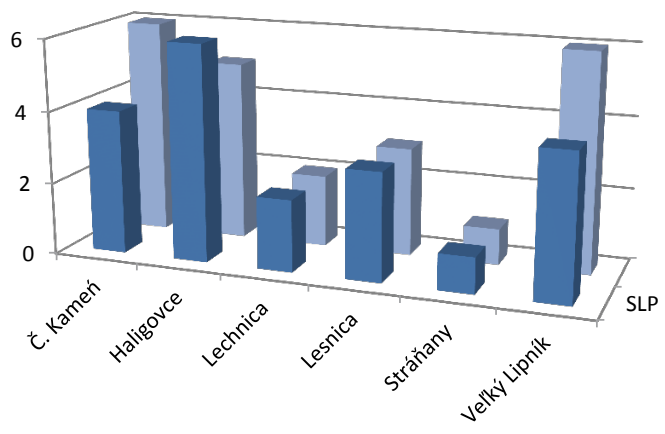

Fig. 7. Comparison of total recreational potential (RP) with selective preconditions (SLP).

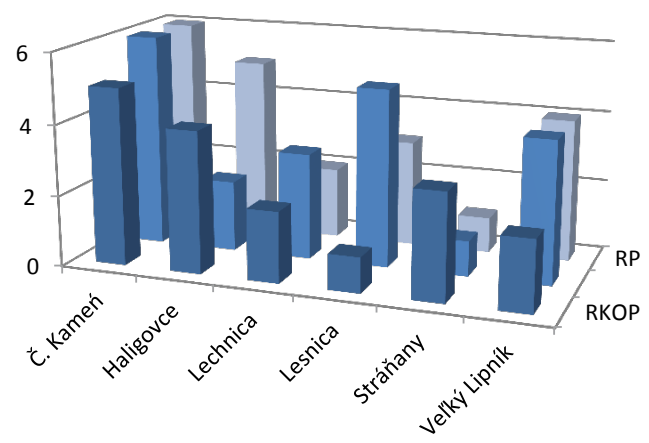

Fig. 8. Comparison of recreational potential (RP) with materialtechnical (RMT) and communication preconditions of the landscape (RKOP). 


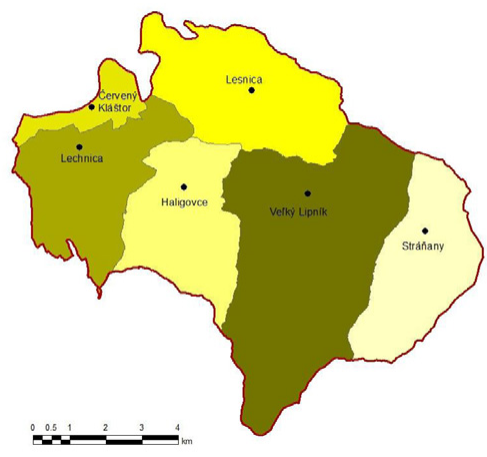

Fig. 9. Spatial image of selective preconditions of the landscape. Notes: 1-lowest, 2 - very low, 3-low, 4-moderate, 5-high, 6-very high.

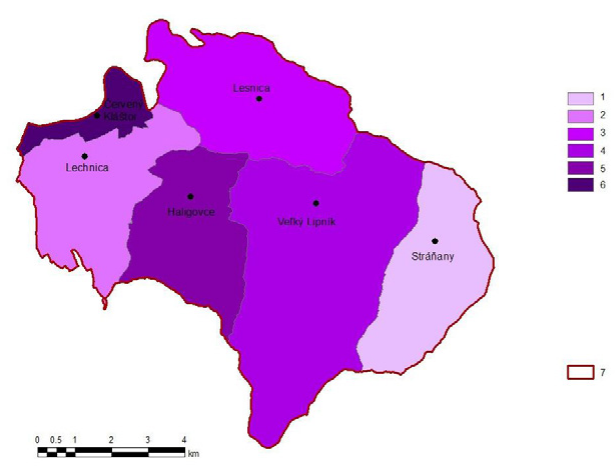

Fig. 10. Spatial image of realization preconditions.

Notes: 1- lowest, 2 - very low, 3- low, 4-moderate, 5-high, 6-very high.

The evaluation of complex tourism preconditions in the whole monitored territory was divided into localizing natural preconditions, localizing semi-natural and cultural- historical preconditions, selective preconditions and realization preconditions resulting from reached multiplications from the groups of preconditions; in order to obtain total tourism precondition rate of particular villages (Table 4).

Complex evaluation and proposed tourism development

\section{Červený Kláštor}

Of all the villages monitored, most of the cultural-societal and sport events have been organized at Červený Kláštor. Accordingly, opportunities should be created to present the folklore, painting arts, traditions and habits typical for the Zamagurie region. Rather high potential of 
$\mathrm{T}$ a b l e 4. Evaluation of the landscape recreational ecosystem services for tourism development.

\begin{tabular}{|c|c|c|c|c|c|c|c|}
\hline & $\begin{array}{c}\text { Bal } \\
\text { value }\end{array}$ & $\begin{array}{l}\text { Červený } \\
\text { Kláštor }\end{array}$ & Haligovce & Lechnica & Lesnica & Stráňany & \begin{tabular}{|l} 
Velký \\
Lipník
\end{tabular} \\
\hline \multicolumn{8}{|l|}{ Localizing natural preconditions } \\
\hline & & 666 & 878 & 865 & 722 & 874 & 883 \\
\hline & & 1 & 5 & 3 & 2 & 4 & 6 \\
\hline \multicolumn{8}{|l|}{$\begin{array}{l}\text { Localizing semi-natural and } \\
\text { cultural-historical preconditions }\end{array}$} \\
\hline Most attractive monument & 5 & 5 & 0 & 0 & 0 & 0 & 0 \\
\hline Attractive monument & 4 & 0 & 4 & 0 & 4 & 0 & 4 \\
\hline Selected HŠKP component & 4 & 4 & 12 & 8 & 12 & 4 & 8 \\
\hline Less attractive monument & 3 & 0 & 3 & 0 & 0 & 0 & 0 \\
\hline Insufficiently attractive monument & 1 & 0 & 0 & 0 & 0 & 0 & 0 \\
\hline Total & & 9 & 19 & 8 & 16 & 4 & 12 \\
\hline Localizing precondition rate & & 3 & 6 & 2 & 5 & 1 & 4 \\
\hline & $\begin{array}{c}\text { Bal } \\
\text { value }\end{array}$ & $\begin{array}{l}\text { Červený } \\
\text { Kláštor }\end{array}$ & Haligovce & Lechnica & Lesnica & Stráňany & \begin{tabular}{|l} 
Velký \\
Lipník
\end{tabular} \\
\hline Selective preconditions & \multicolumn{7}{|c|}{ Multiplication of likelihood rates and bal value } \\
\hline Settlement size & 9 & 9 & 27 & 18 & 18 & 9 & 27 \\
\hline Social group & 8 & 24 & 16 & 8 & 24 & 8 & 16 \\
\hline Life standard indicators & 7 & 21 & 7 & 7 & 14 & 21 & 14 \\
\hline Economic activity & 6 & 12 & 18 & 12 & 6 & 6 & 18 \\
\hline Education structure & 6 & 18 & 12 & 6 & 6 & 18 & 12 \\
\hline Age structure & 5 & 15 & 15 & 10 & 5 & 5 & 10 \\
\hline Residential fund & 4 & 4 & 12 & 12 & 8 & 4 & 8 \\
\hline Gender structure & 2 & 2 & 6 & 4 & 6 & 2 & 6 \\
\hline Population density & 1 & 3 & 3 & 1 & 2 & 1 & 2 \\
\hline Total & & 108 & 116 & 78 & 89 & 74 & 113 \\
\hline Selective precondition rate & & 4 & 6 & 2 & 3 & 1 & 5 \\
\hline & $\begin{array}{c}\text { Bal } \\
\text { value }\end{array}$ & $\begin{array}{l}\text { Červený } \\
\text { Kláštor }\end{array}$ & Haligovce & Lechnica & Lesnica & Stráňany & \begin{tabular}{|l|} 
Velký \\
Lipník \\
\end{tabular} \\
\hline Realization preconditions & \multirow{2}{*}{\multicolumn{7}{|c|}{ Multiplication of likelihood rates and bal value }} \\
\hline Communication preconditions & & & & & & & \\
\hline Total & 1 & 25 & 23 & 16 & 15 & 22 & 27 \\
\hline Communication precondition rate & & 5 & 4 & 2 & 1 & 3 & 6 \\
\hline Material-technical preconditions & \multicolumn{7}{|c|}{ Multiplication of likelihood rates and bal value } \\
\hline Hotel & 5 & 5 & 0 & 0 & 0 & 0 & 0 \\
\hline Pension & 4 & 16 & 4 & 0 & 16 & 0 & 4 \\
\hline Restaurant & 3 & 9 & 3 & 0 & 3 & 0 & 6 \\
\hline Accommodation facility & 2 & 0 & 0 & 0 & 2 & 0 & 0 \\
\hline Summer house camp & 2 & 0 & 0 & 2 & 0 & 0 & 0 \\
\hline Sport places of local importance & 1 & 1 & 1 & 1 & 1 & 1 & 1 \\
\hline Cultural - societal events & 4 & 16 & 0 & 4 & 0 & 0 & 0 \\
\hline Sport events & 3 & 15 & 0 & 0 & 0 & 0 & 0 \\
\hline Intangible cultural-historical monument & 1 & 3 & 0 & 2 & 0 & 0 & 0 \\
\hline Total & & 65 & 8 & 9 & 22 & 1 & 11 \\
\hline Material-technical precondition rate & & 6 & 2 & 3 & 5 & 1 & 4 \\
\hline All preconditions - total & & 207 & 166 & 111 & 142 & 101 & 163 \\
\hline Total rate of tourism preconditions & & 6 & 5 & 2 & 3 & 1 & 4 \\
\hline
\end{tabular}


human resources created preconditions for more activities to be performed by the interested organizations that could offer complex services to tourists and service providers. From an environmental point of view, the village represents a part of PIENAP, and is situated in A, $\mathrm{B}$ - nature protection zones. These zones include the national natural reservation Prielom Dunajca and protected area Pieninské lipy. The required quality standards should be met at permanently sustainable tourism management, so that they do not exceed the boundaries of ecological and psycho-social capacity of the national park territory. In case of investment projects to be implemented, it is necessary to primarily respect the existence of the PIENAP protected territory pursuant to the Act of Landscape and Nature Protection. The lowest rate was assigned to the village in case of localizing natural preconditions of tourism because of unfavourable proportion of attractive and major landscape-creation components in the village, and higher proportion of permanent cultures that are not suitable for development of tourism. The village had favourable inner communication accessibility and as such, it reached high rate of realization preconditions. As for selective preconditions, the village reached medium rate for proportion of likely active participation of inhabitants and based on the criterion 'average residential area per capita'. According to the processed statistical data (Statistical Office of the Slovak Republic, 2011), it is a village typical with permanent stagnation of inhabitants.

\section{Lechnica}

As for tourism localizing preconditions, the village was assigned with low rate because of unfavourable ratio of major landscape-creation components and permanent cultures area. Vast areas of permanent grass vegetation provide sufficient room for sheep breeding. Territory of village Lechnica has tourism development potential in the form of agro-tourism that could increase employment and attract vacationers. The cadastre territory is situated in D-zone of the PIENAP. The village reached very low communication accessibility within the realization preconditions of tourism, similar to selective preconditions. Permanent reduction of the inhabitants' headcount has been reported at the village. Its active participation in tourism is less likely, considering its age, education structure and economic activity.

\section{Lesnica}

Cultural-historical preconditions of the village are represented by St. Michael's Church dated in the half of the 18th century. As for nature protection, the village has been classified in $\mathrm{A}$, $\mathrm{B}, \mathrm{C}$ - PIENAP zone of the nature protection. These zones also include the national natural monument called 'Prielom Lesníckeho potoka'. The village does not have a large area of SLS (secondary landscape structure) components suitable for tourism, thus it reached very low rate of localizing preconditions of tourism in the nature. As for communication accessibility within the realization preconditions of tourism, the village reached the lowest rate of the inner communication accessibility. In the area of inner accessibility, we recommend creating more daily bus lines at the village during tourist season, in cooperation with company BUS KARPATY, spol. s.r.o. As for selective preconditions, the village reached a low rate. As 
the only in the monitored territory, the village reports permanent increase of the inhabitant headcount.

\section{Haligovce}

Cadastre territory of village Haligovce is situated in A, B, C and D - zone of the PIENAP. We recommend maintaining the management within the nature protection in zone $\mathrm{A}$, annual cleaning of the locations and restoration of traditional agriculture in the biotopes with xerothermal nature and the occurrence of host plants, for example, significant biotope of Parnassius apollo. As for communication accessibility within the realization preconditions of tourism, the village Haligovce reached medium rate. Selective preconditions of tourism reached the highest rate in this village. Haligovce ranks among the villages with permanent population stagnation, favourable age structure and economic activity of inhabitants. In terms of selective preconditions, we recommend dedicating efforts to the local inhabitants, giving them room for enjoying their hobbies in favour of the society.

\section{Vel'ký Lipník}

Realization preconditions of tourism - material-technical base of the village Velký Lipník reached medium rate. There are recreational, accommodation facilities and houses in the village, built in the original architecture typical for the Zamagurie region. The village reached medium rate also in localizing semi-natural and cultural - historical preconditions of tourism. The Greek-Catholic St. Michael's Church represents the village dominance. Traditionally used as agricultural small-size fields, contributing to the landscape character of the territory represents a major landscape-creating element (104.01 ha of total area 2,751.3 ha). As for environmental preconditions, the village is included in the PIENAP zone $\mathrm{B}, \mathrm{C}$ and $\mathrm{D}$. Amongst all villages located in the monitored territory, Velký Lipník is the highest rated village in the terms of localizing preconditions of tourism in the nature. Rural area consists mostly of forests and areas permanently covered by grass. Taking this precondition into account, we suggest providing for careful and sustainable economy of the forest areas, extensive mowing and grazing permanently grass-covered areas without disturbing the balks and cutting excessive fly wood. As for the communication accessibility within the realization preconditions of tourism, the village reached the highest rate in the terms of inner accessibility. The village ranks among the villages with permanent population stagnation with favourable proportion of productive population and high proportion of economic-active population.

\section{Stráňany}

Village Stránany reached the lowest rate in the area of realization preconditions of tourist material-technical base, since there is neither accommodation nor boarding facilities in the village. Local sporting place serves to various sport activities in the village. We suggest maintaining the unique rural architecture in the village. As for the realization preconditions of tourism, we recommend supporting the inhabitants in becoming more interested in ac- 
quisition of competences, experience in private accommodation of tourists, yard sales, family businesses, small businesses - all these activities are aimed at reducing unemployment rate. As for localizing semi-natural and cultural - historical preconditions of tourism, village Stránany reached the lowest rate. No cultural monument is located in the village. Cadastre territory of village Stráňany is located in B, C and D - zone of the nature protection. Regarding the localizing preconditions of the tourism in the nature, the area of SLS (secondary landscape structure) components suitable for tourism reached the medium rate, thus we suggest taking into consideration the opportunities of summer tourism and agricultural tourism in the village. As for communication accessibility within the realization preconditions of tourism, the village reached low rate, and the lowest rate in the area of selective preconditions of tourism. The population trend has been decreasing on a long-term basis, and the expected participation of the inhabitants in tourism is low, taking into account the population density, age structure and economic activity.

\section{Conclusion}

Tourism is often the only area of new jobs creation, development of villages and elimination of population emigration in the mountain and uphill areas, for example the Zamagurie region with conditions unfavourable for agriculture and industry. The Walachian and Sholtys colonization has transformed the landscape and created unique significant spatial landscape elements that are traditionally utilized for agricultural purposes and create a unique esthetical landscape saved till the present times. Support of farmer-type tourism development would eliminate emigration of the Zamagurie region population on one hand, and contribute to maintaining traditional economy and support of farmer landscape uniqueness on the other hand.

\section{Acknowledgements}

The case study was prepared within solving the project VEGA No. 02/0051/17 funded by the Scientific Grant Agency of the Slovak Ministry of Education, Science and Sport, and the Slovak Academy of Sciences (SAV): The evaluation of cultural ecosystem services in the landscape on a basis of landscape-ecological research for the development of ecological tourism models. “

\section{References}

Drábová, M. (2015). Potenciál krajiny vo vzṫahu k rozvoju cestovného ruchu vybraného územia Zamaguria. Dizertačná práca, ÚKE SAV, Bratislava, UKF Nitra.

Ferner, F. (1993). Marketing cestovného ruchu v praxi. Bratislava : SPN.

Futák, J. (1972). Fytogeografický prehlad Slovenska. In J. Lukniš (Ed.), Slovensko 2. Príroda (pp. 431-482). Bratislava: Príroda.

Gondová, M., Reed, T. \& Tvrdoňová J. (2000). Rozvoj podnikania vo vidieckej turistike a agroturistike (Praktický sprievodca pre podnikatelov). Nitra: Agroinštitút Nitra.

Hall, D., Kirkpatrick, I. \& Mitchell M. (2005). Aspects of tourism: Rural tourism and sustainable business. Oxford: Cromwell Press.

Horner, S. \& Swarbrooke J. (2003). Cestovní ruch, ubytování a stravování, využití volného času. Aplikovaný marketing služeb. Praha: Grada Publishing. 
Jedlička, L. \& Kalivodová E. (2002). Zoogeografické členenie Slovenska. In Atlas krajiny Slovenskej republiky (p. 344). Bratislava: MŽP SR.

Kaspar, C. (1995). Základy cestovného ruchu. Banská Bystrica: Trian.

Kopšo, E., Gúčik, M. a kol. (1992). Geografia cestovného ruchu. Bratislava: SPN.

Krnáčová, Z., Štefunková, D., Dobrovodská, M., Hrnčiarová, T., Pavličková, K., Pauditšová, E., Potočková, E., Košovič, P., Kubíček, F., Janotka, V. \& Gajdoš V. (2005). Integrovaný rozvoj turizmu v mikroregióne Svätý Jur. Bratislava: ÚKE SAV.

Krnáčová, Z. (2014). Vedecké poznanie a výskum metód pri tvorbe ekologických modelov rozvoja cestovného ruchu. Životné Prostredie, 48(4), 213-216.

Krogmann, A. (2005a). Aktuálne možnosti využitia potenciálu územia Nitrianskeho kraja z hladiska cestovného ruchu. Nitra : UKF.

Krogmann, A. (2005b). Využitie modelov v geografii cestovného ruchu. GEO Information, 1, 242-248.

Krogmann, A. (2006). Percepcia vybraných stredísk cestovného ruchu v Nitrianskom kraji ich návštevníkmi. Geografická Revue, 2(2), 340-351.

Mariot, P. (1983). Geografia cestovného ruchu. Bratislava: VEDA, vydavatel'stvo SAV.

Mazúr, E. \& Lukniš M. (1986). Geomorfologické členenie SSR a ČSSR. Čast Slovensko. Bratislava: Slovenská kartografia.

McIntosh, R.W. \& Goeldner CH.R. (1990). Tourism: principles, practices, philosophies. New York: John Wiley \& Sons.

Michniak, D. (2014). Dostupnost polsko-slovenského pohraničia verejnou a individuálnou dopravou z hladiska rozvoja cestovného ruchu - vybrané prístupy. In GIS Ostrava 2014 : Geoinformatika v pohybu (pp. 1-8). (online). Ostrava : VŠB - Technical University Ostrava. http://gis.vsb.cz/GIS_Ostrava/GIS_Ova_2014/sbornik/ papers/gis2014523976d13776e.pdf

Nováková, E. \& Frantál B. (2007). Př́rodní potenciál cestovního ruchu Vranovska a Podyjí. In Sborník př́spěvků zX. mezinárodního kolokvia o regionálncíh vědách (pp. 356-363). Brno: Masarykova univerzita.

Otrubová, E. (1996). Human geography. University textbook. Bratislava: PriF UK.

Petrovič, F., Bugár, G. \& Hreško J. (2009). Zoznam krajinných prvkov mapovatelných na území Slovenska. GEO Information, 5, 112-124.

Statistical Annual Report of the Slovak Republic (2002). Bratislava: Perfekt.

Statistical Annual Report of the Slovak Republic (2011). Bratislava: Perfekt.

Thematic maps in digital form - internal ground document of ZB GIS (2013). Banská Bystrica: Esprit. The layer: geological conditions, relief types, climatic sub-types, hydrological conditions.

Vanslenbrouck, I. \& Huylenbroeck G. (2005). Landscape amenities: economic assessment of agricultural landscapes. Drodrecht: Springer.

Warszyńska, J. \& Jackowski A. (1978). Podstawy geografii turyzmu. Warszawa:PWN.

Wieckowski, M. et al. (2012). Polsko-slovenské pohraničie z hladiska dopravnej dostupnosti a rozvoja cestovného ruchu. Warszawa: Instytut Geografii i Przestrzennego, Zagospodarowania Polskiej Akademii Nauk, Bratislava: GÚ SAV.

Williams, S. (2004). Tourism. Critical concepts in the social sciences. London: Routledge.

World Tourism Organization (WTO) (2004). 